\title{
Carbohydrate metabolism during new root growth in transplanted Larix olgensis seedlings: post-transplant response to nursery-applied inorganic fertilizer and organic amendment
}

\author{
Hongxu Wei ${ }^{(1)}$, Peng Guo ${ }^{(2)}$
}

\section{Introduction}

Larch species (Larix spp.) have both ecological and commercial values in their native range. They are the focus of many restoration, afforestation, and commercial reforestation efforts in both boreal and temperate forests of the northern hemisphere (Park et al. 2012, Aghai et al. 2014).

\begin{abstract}
Sustainable agriculture often requires the incorporation of organic matter into cultural protocols as an amendment to mitigate problems caused by chemical inputs, but the responses of transplanted seedlings to such additions have not been well quantified. In this study, bare-root Changbai larch (Larix olgensis Henry) seedlings were applied with 100 or $200 \mathrm{~kg}^{2}$ nitrogen $(\mathrm{N}) \mathrm{ha}^{-1}$ of inorganic fertilizer with or without chicken manure added at a rate of $10,000 \mathrm{~kg} \mathrm{ha}^{-1}$ during nursery cultivation, obtaining four treatment combinations designated as $\mathrm{F} 100+$, F200+, F100-, and F200-, respectively. Over-winter seedlings were transplanted into pots and placed in a growth chamber, where the carbohydrate metabolism, biomass accumulation, root respiration, and new root number were quantified. Both initial soluble sugar and total non-structural carbohydrate (TNC) accumulation were the lowest in the F100+ treatment. However, two months later, root soluble sugar content was the highest in this treatment, while coarse-root (diameter $>2 \mathrm{~mm}$ ) carbohydrate content was the highest in the low rate of inorganic fertilizer treatment. During the two-month post-transplant period, the net carbohydrate accumulation rate (NCAR) for starch was negative for all treatments, but the NCAR value for soluble sugars was the highest in the $\mathrm{F} 100+$ treatment at both the root and whole-plant scales. Relative to the F200- treatment, the NCAR value for soluble sugars, final sugar content, and biomass accumulation in coarse roots, respiration rate of fine roots (diameter $\leq 2 \mathrm{~mm}$ ), and new root number were all greater in the F100 + treatment, while new root number was increased by organic matter additions. In conclusion, the use of chicken manure as an organic amendment had the potential to enhance transplanted larch seedling performance by improving post-transplant new root number, but this application must be considered within the context of the interaction between organic amendment treatments and inorganic fertilizer applications.
\end{abstract}

Keywords: Changbai Larch, Organic Additive, Mineral Fertilizer, New Root Egress, Starch, Soluble Sugars

However, larch seedlings are facing many challenges to successfully establish due to harsh environments caused by climate change and soil degradation (Watanabe et al. 2012, Eilmann \& Rigling 2012). Consequently, to maintain low mortality and high productivity of newly planted larch seedlings through improving seedling quality $\square$ (1) Northeast Institute of Geography and Agricultural Ecology, Chinese Academy of Sciences, Changchun City, Jilin Province, 130102 (China); (2) Environment and Resources College, Dalian Nationalities University, Dalian City, Liaoning Province, 116600 (China)

@ Peng Guo (gp@dlnu.edu.cn)

Received: Jan 19, 2016 - Accepted: Jun 21, 2016

Citation: Wei H, Guo P (2016). Carbohydrate metabolism during new root growth in transplanted Larix olgensis seedlings: post-transplant response to nursery-applied inorganic fertilizer and organic amendment. iForest 10: 15-22. - doi: 10.3832/ifor1988-009 [online 2016-09-22]

Communicated by: Claudia Cocozza will have both economic and ecological ramifications for larch afforestation.

Root characteristics strongly influence the performance of transplanted tree seedling (Cuesta et al. 2010a). Seedling root quality is considered as a critical parameter relating to post-transplant seedling performance (Aghai et al. 2014) in terms of architecture and developmental patterns (Wilson et al. 2007). At nursery stage, nitrogen $(\mathrm{N})$ fertilization has been proven to foster seedling root growth, and subsequently to enhance post-transplant seedling performance (Cuesta et al. 2010a, 2010b). However, over-application of inorganic $\mathrm{N}$ fertilizers beyond the optimal rate may induce inherent toxicity in seedlings (Salifu \& Jacobs 2006, Duan et al. 2013) and result in chemical contamination of groundwater through leaching (Klooster et al. 2012, Park et al. 2012). Sustainable agriculture often requires organic matter to be incorporated into cultural protocols as an amendment to mitigate problems associated with chemical inputs and to improve soil physical pro- 
perties (Wei et al. 2012a). Organic matter may be added to soils as a substitute for some inorganic fertilizers during tree seedling cultivation so as to alleviate the potential negative impacts of chemical inputs on the environment. For larch seedlings, simultaneous uses of both organic amendments and inorganic fertilizer were found to have a positively interactive effect on nutrient reserves and root quality during nursery culture (Wei et al. 2012a). However, to our knowledge, current literature has not documented sufficient information about post-transplant larch seedling performance with regard to the responses of root growth and carbohydrate metabolism to nursery-applied organic amendments and inorganic fertilizer.

New root production in post-transplant tree seedlings has been demonstrated to rely on stored carbohydrates for several tree species (Sloan \& Jacobs 2008, Vargas et al. 2009). Stored carbohydrates are required by newly planted seedlings not only as metabolic substrates but also as regulatory signals for new root growth (Willaume \& Pagès 2011). A high proportion of total non-structural carbohydrates (TNC) are consumed by root respiration (Druege et al. 2000, 2004) for maintaining ion gradients across cell membranes and for the maintenance and replacement of proteins, membranes, and other constituents. Roots within different diameter classes have different respiration rates (Chen et al. 2010, Jia et al. 2013), mostly due to changes in diameter-related surface-areas without significant changes in lignification area. However, root carbohydrate metabolism during new root growth has not been thoroughly investigated in newly planted seedlings. It is not clear whether the response of carbohydrate metabolism would change if post-transplant seedlings had different initial carbohydrate statuses.

In China, about 31\% of the total forested area is in the northeast region of the country (including Heilongjiang, Jilin, and Liaoning Provinces), corresponding to a forested area of $\sim 47 \times 10^{4} \mathrm{~km}^{2}$ (Zhang 2007). Larch has been promoted for planting as a typical fast-growing tree species by government policy in China for years (Zhang et al. 2000). The northeast Chinese region accounts for $73 \%$ ( $\sim 4.7$ million hectares) of the total larch plantations in China (You et al. 2013). Changbai larch (Larix olgensis Henry) is one of the most important larch species in Northern China and many other areas of eastern Asia. Recently, it was reported that Changbai larch plantations are declining in distribution or being replaced by other tree species, which was partly the result of low quality of locally cultured Changbai larch seedlings (Wei et al. 2013, 2014, Duan et al. 2013). In a previous study, we found that the interaction between a nursery-applied organic amendment and inorganic fertilizer had a positive effect on the quality of Changbai larch seedlings (Wei et al. 2012a). This implied that Changbai larch seedlings receiving these nursery treatments would exhibit improved post-transplant performance, but currently no evidence is available to support this hypothesis. In the present study, the same lots of seedlings cultured from the previous study were transplanted to a controlled environment to quantify root performance characteristics. It was hypothesized that: relative to the application of inorganic fertilizer at nursery stage, the combined effects of organic amendment and inorganic fertilizer would result in (1) more carbohydrate reserves and biomass accumulation, (2) higher rates of root respiration, and (3) more new roots.

\section{Materials and methods}

\section{Nursery culture of seedlings and} fertilization treatments

Changbai larch seedlings were cultured as bare-root stocks in an open-air nursery $\left(43^{\circ}\right.$ $\left.45^{\prime} \mathrm{N}, 126^{\circ} 45^{\prime} \mathrm{E}\right)$ near Jilin City, Jilin Province, Northeast China. In local region, the annual precipitation is 650 to $750 \mathrm{~mm}$ with less than $200 \mathrm{~mm}$ from May to mid-June, and the mean annual temperature is 3 to 5 ${ }^{\circ} \mathrm{C}$ with a mean temperature of $6.5^{\circ} \mathrm{C}$ in the early growing season. Soils in the nursery were determined to have $4.79 \mathrm{mg} \mathrm{kg}^{-1} \mathrm{NH}_{4}^{+}-$ $\mathrm{N}, 192.88 \mathrm{mg} \mathrm{kg}^{-1} \mathrm{NO}_{3}-\mathrm{N}, 1.60 \mathrm{mg} \mathrm{kg}^{-1}$ available $\mathrm{P}, 0.10 \mathrm{dS} \mathrm{m}^{-1} \mathrm{EC}_{2.5}$, and a $\mathrm{pH}$ of 6.51 . More specific soil properties can be found in Wei et al. (2012a).

Seeds were collected by employees of Xiaobeihu Forest Station $\left(44^{\circ} 03^{\prime} \mathrm{N}, 128^{\circ} 28^{\prime}\right.$ E) from a local wild stand in Heilongjiang Province, Northeast China. After collection, seeds were transported to the nursery and stored at temperature $0-4{ }^{\circ} \mathrm{C}$. Before sowing, locally prescribed ammonium phosphate (18-46-0) was applied into surface soils $(0-20 \mathrm{~cm})$ at a rate of $54 \mathrm{~kg} \mathrm{~N} \mathrm{ha}^{-1}$ in late April. The use of ammonium phosphate and its application rate has been employed as a practical fertilization protocol for Larch culture in Jilin for many years (Wei et al. 2011). Seeds were soaked in $5 \%$ potassium permanganate $(\mathrm{w} / \mathrm{w})$ solution for $24 \mathrm{~h}$, stratified for 5 days at $0-4{ }^{\circ} \mathrm{C}$, and sown at a density of 700 seeds $\mathrm{m}^{-2}$ on 3 May 2009. In mid-June 2009, germinated seedlings were thinned to a density of about 550 seedlings $\mathrm{m}^{-2}$. Thinned seedlings were then fertilized at the rate of $200 \mathrm{~kg} \mathrm{~N}$ $\mathrm{ha}^{-1}$ (F200) using ammonium nitrate (21-0-0) and urea (46-0-0). This rate was performed as the standard practical dose for inorganic fertilizer application of bare-root Changbai larch seedlings locally in Jilin (Wei et al. 2012a, Duan et al. 2013). The other inorganic fertilizer treatment was applied at a lower rate of $100 \mathrm{~kg} \mathrm{~N} \mathrm{ha}^{-1}$ (F100), which was found to result in a fair seedling quality at the end of the nursery production stage (Wei et al. 2012b). Chicken manure was chosen as the organic additive, which had undergone natural decomposition outdoors for nearly 12 months prior to the experiment and consisted of a local mixture of chicken feces and some soil from the southeastern part of the nursery. Chemical analysis revealed that total N, P and $K$ contents within the chicken manure were $11.93,8.22$ and $12.34 \mathrm{~g} \mathrm{~kg}^{-1}$, respectively, with an EC of $3.51 \mathrm{dS} \mathrm{m}^{-1}$ and a pH of 8.23. High $\mathrm{pH}$ values above 8.0 have also been reported in other chicken manures and their mixtures in compost in other regions (Davis et al. 2006, Irshad et al. 2013). More specific properties of the chicken manure used in the present study can be found in Wei et al. (2012a). Chicken manure was incorporated evenly into amended soils to a depth of $10-15 \mathrm{~cm}$ by hand-raking at a rate of $0(-0)$ or $10,000 \mathrm{~kg}$ (fresh weight) ha-1 $(+O)$. Chicken manure was applied immediately after the seedling beds were shaped but before the application of basal inorganic fertilizer in late April. Therefore, fertilization treatments were performed as two inorganic fertilizer regimes (the F100 and F200 treatments) combined with or without an organic matter addition (the $+O$ and $-O$ treatments, respectively), which was conducted as a $2 \times$ 2 factorial design containing 4 combined treatments (F100+, F100-, F200+, F200-). Therein, the combined treatment of inorganic fertilizer without organic matter added as an amendment (F200-) was considered to be the control treatment. This treatment is also used as the standard practice for fertilization of bare-root Changbai larch seedlings locally in Jilin Province (Wei et al. 2012a). The experiment was arranged as a randomized complete block design. Three replicated plots were randomly placed for one combined treatment. Each plot had an area of $1 \times 1 \mathrm{~m}$ with 0.1 to 0.2 m-width buffers between adjacent plots, where plastic barriers were inserted to a depth of $0.2 \mathrm{~m}$ to eliminate the potentially lateral movement of nutritional elements between plots.

\section{Seedling sampling and over-winter storage}

On 12 October 2009, when seedlings had formed apical buds and needles were about to fall, they were carefully handlifted with a shovel so as to maintain the whole root system intact. Excavated seedlings were separated into three categories according to their sizes. Sixteen seedlings per nursery plot were then randomly collected from the large-sized seedling category (height $\geq 11 \mathrm{~cm}$, root collar diameter - RCD $\geq 3 \mathrm{~mm}$ ). Rhizosphere conditions were assumed to be uniform for all investigated seedlings. Large seedlings were used because they met the top I grade of the national standard for larch seedling quality in China and are the preferred size class for use in local larch afforestation. Sampled seedlings were grouped and labeled by treatment combination and nursery plot, then carefully washed to clean residual soil from roots using tap water and rinsed with distilled 
water. Roots were handled carefully throughout this procedure to avoid unnecessary damage. Cleaned seedlings were then transported to the Laboratory of Silviculture and Forest Management, Beihua University ( $\left.43^{\circ} 84^{\prime} \mathrm{N}, 126^{\circ} 61^{\prime} \mathrm{E}\right)$, Jilin City, Jilin Province, Northeast China, and stored in darkness at $0-4{ }^{\circ} \mathrm{C}$ to overwinter.

Growth chamber transplant experiment

On 22 April 2010, one hundred and ninetytwo seedlings, i.e., 16 seedlings per plot at nursery stage, were transported on ice to the laboratory of Beijing Forestry University $\left(40^{\circ} 00^{\prime} \mathrm{N}, 116^{\circ} 35^{\prime} \mathrm{E}\right)$. Two seedlings per plot at nursery stage were measured for their initial height, RCD, and biomass, while an additional two seedlings were destructively harvested to determine initial shoot and root biomass and carbohydrate content. Hence, a total of 48 seedlings were used for initial measurements. The other 144 seedlings (12 seedlings per plot at nursery stage) were moved to an artificially controlled climatic chamber in the Experimental Forest Station of Beijing Forestry University $\left(40^{\circ} 07^{\prime} \mathrm{N}, 116^{\circ} 11^{\prime} \mathrm{E}\right)$ at Jiufeng Forest Park, Beijing, China. Seedlings were transplanted into pots $(10 \times 7 \times 20$ $\mathrm{cm}$, top diameter $\times$ bottom diameter $\times$ height, one seedling per pot) filled with 1:1 (V/V) Pindstrup ${ }^{\oplus}$ substrate (SP., Pindstrup Mosebrug A/S, Ryomgaard, Denmark) and vermiculite. In the climatic chamber, day/ night air temperature was set to be $26 / 20$ ${ }^{\circ} \mathrm{C}$ with $70 \%$ relative humidity $(\mathrm{RH})$ and an $18 \mathrm{~h}$ photoperiod. An $\mathrm{RH}$ of $70 \%$ approximates the annual ambient $\mathrm{RH}$ of the native range of Changbai larch near Changbai Mountain (Zhang \& Li 1984). This RH also approximates to occur at one $\mathrm{m}$ height aboveground where bare-root Changbai larch seedlings are cultured in Jilin (Xu et al. 2010). Illumination was provided by 200$W$ plant growth lamps (Oudi ${ }^{\mathrm{TM}} \mathrm{Co}$., Huzhou, Zhejiang, China), which promised a photosynthetic photon flux density (PPFD) to be $150 \mu \mathrm{mol} \mathrm{m} \mathrm{m}^{-2} \mathrm{~s}^{-1}$ measured at seedling apical tip. The 18 -h photoperiod has been considered sufficient for seedling growth and a PPFD of $\sim 150 \mu \mathrm{mol} \mathrm{m} \mathrm{m}^{-2} \mathrm{~s}^{-1}$ was the light intensity observed in the environment where Changbai larch saplings were regenerated (Zhu et al. 2008, Wei et al. 2013). All transplanted seedlings were watered using nutritional solutions every two days at a rate of $200 \mathrm{ml}^{\text {seedling }}{ }^{-1}$ each time. The solution included essential mineral elements which have been found to benefit growth of transplanted Changbai larch seedlings (Wei et al. 2013). Briefly, solutions delivered a total sum of nutrients per year: $4 \mathrm{mM} \mathrm{NH}_{4} \mathrm{NO}_{3}, 0.5 \mathrm{mM} \mathrm{K}_{2} \mathrm{HPO}_{4}, 0.5$ $\mathrm{mM} \mathrm{KCl}, 1 \mathrm{mM} \mathrm{CaCl}$, $0.6 \mathrm{mM} \mathrm{MgSO}{ }_{4} \cdot 7 \mathrm{H}_{2} \mathrm{O}$, $20 \mu \mathrm{M} \mathrm{FeCl} \cdot 6 \mathrm{H}_{2} \mathrm{O}, 6 \mu \mathrm{M} \mathrm{MnCl} \cdot 4 \mathrm{H}_{2} \mathrm{O}, 16 \mu \mathrm{M}$ $\mathrm{H}_{3} \mathrm{BO}_{3}, 0.3 \mu \mathrm{M} \mathrm{ZnCl}, 0.3 \mu \mathrm{M} \mathrm{CuCl} \cdot \cdot 2 \mathrm{H}_{2} \mathrm{O}$, and $0.3 \mu \mathrm{M} \mathrm{NaMoO} \cdot 2 \mathrm{H}_{2} \mathrm{O}$. All pots were randomly placed and rearranged every two days so as to eliminate possible edge effects.
Sampling, measurement, and chemical analysis of transplanted seedlings

Transplanted seedlings were harvested and transported to the laboratory of Beijing Forestry University on 22 June 2010. Twelve harvested seedlings per plot at nursery stage were separated into three groups with each including four seedlings. New roots were characterized as white, supple, and un-lignified ones, while old roots were brown and lignified. Roots of seedlings were washed free of substrates before being cut and separated into shoots and roots, and roots was further separated into three diameter classes: coarse roots (diameter $>2 \mathrm{~mm}$ ), medium fine roots (diameter of 1-2 mm), and very fine roots (diameter of 0-1 mm). The number of new roots for each seedling was measured by counting for white juvenile root tips. Thereafter, biomass of each separated seedling sections was measured after being ovendried at $70^{\circ} \mathrm{C}$ for $48 \mathrm{~h}$.

The respiration rates of roots within different diameter classes were measured using an infrared gas analyzer (IRGA) Model 7000 (Li-Cor, Inc., Lincoln, NE, USA), which was connected by a columnar cuvette $(9.5 \times 3 \mathrm{~cm}$, length $\times$ inner diameter). During the measurement, root sections were folded in wet paper towels and placed into the cuvette, which was wrapped with aluminum foil so as to keep the inside completely dark. Both ends of the cuvette were sealed with rubber plugs through which two tubes were inserted to create both airflow entrance and exit. Each measurement was allowed to equilibrate for 15 min until the maximum $\mathrm{CO}_{2}$ concentration reached approximately $1,000 \mu \mathrm{mol}$ $\mathrm{mol}^{-1}$ and a $\mathrm{RH}$ of $80 \%$ with a temperature range from 27 to $28{ }^{\circ} \mathrm{C}$. The $\mathrm{CO}_{2}$ efflux rate was logged every $0.5 \mathrm{~s}$ from its steadystate, with an air velocity of approximately 1.25 $\mathrm{L} \mathrm{min}^{-1}$. During the measurement, a technical control was involved with no sampled roots placed in the cuvette, and the mean respiration rate of controls was subtracted from root respiration values.

Carbohydrate concentrations of seedling organs were analyzed after the fresh mass measurement. Determination methods were adapted from Wei et al. (2014): a 0.5 g sample was placed in a $10 \mathrm{ml}$ glass test tube with $5 \mathrm{ml}$ distilled water inside, covered by a plug, and incubated in a boiling water bath for $1 \mathrm{~h}$. After removal of the supernatant (which was used for soluble sugar determination as described below), the residue was washed with $25 \mathrm{ml}$ distilled water and oven-dried at $70{ }^{\circ} \mathrm{C}$ for $48 \mathrm{~h}$. Starch was extracted from this dried residue with an $\mathrm{HCl}$ extraction method: $5 \mathrm{ml}$ of $3 \% \mathrm{HCl}$ was added to a test tube with the residue, which was then hydrolyzed in a boiling water bath for $3 \mathrm{~h}$. Soluble sugar and starch contents were determined by a colorimetric method: one $\mathrm{ml}$ extracted solution was filtered through Whatman No. 42 filter paper into a $50 \mathrm{ml}$ volumetric flask to which $1 \mathrm{ml}$ of $25 \% \mathrm{HCl}$ was then added, and the solution was hydrolyzed for 30 minutes; next, $1 \mathrm{ml}$ of a $28 \%$ phenol solution was added, immediately by $5 \mathrm{ml}$ of concentrated sulphuric acid added rapidly, directing the stream on to the liquid surface. The flask was then shaken by hand for $1 \mathrm{~min}$, cooled at room temperature for 5 min, neutralized with $\mathrm{NaOH}$ solution, and diluted to the volume of $50 \mathrm{ml}$ with distilled water. Carbohydrate concentration was determined using a spectrophotometer at $490 \mathrm{~nm}$ (UV-Visible 8453, Agilent Technologies Inc., Santa Clara, CA, United States).

Parameter calculation and data analysis Net carbohydrate accumulation rate (NCAR) was calculated as (eqn. 1):

$$
N C A R=\frac{\ln C C_{2}-\ln C C_{1}}{t_{2}-t_{1}} \cdot 1000
$$

where $C C_{1}$ and $C C_{2}$ were the total nonstructural carbohydrate contents $(\mu \mathrm{g})$ in the seedlings sampled at day $t_{1}$ and $t_{2}$, respectively; $t_{1}(\mathrm{~d})$ and $t_{2}(\mathrm{~d})$ represent the time when seedlings were transplanted and harvested, respectively.

For post-transplant data analysis, new root numbers, biomass, carbohydrate (sugar, starch, and TNC) concentrations and contents (concentration $\times$ biomass), NCAR and root respiration rates were tested as dependent variables. The inorganic fertilizer treatment and organic amendment were included as main effects, and each treatment combination was represented by three replicates $(n=3)$. Data were analyzed using the General Linear Model (GLM) in SAS 9.0 (SAS Institute Inc., Cary, NC, USA). For pre-transplant seedlings, root biomass and carbohydrate contents were analyzed as dependent variables as described above. For transplanted seedlings, new root number, biomass, carbohydrate contents, $N C A R$, and root respiration rate were compared separately for each root diameter class. When analysis of variance (ANOVA) indicated significant effects $(P<0.05)$, Tukey's Studentized Range Test was used to identify the significant differences among treatments $(\alpha=0.05)$.

\section{Results}

\section{Seedling carbohydrate storage in roots before transplant}

On 22 April 2010, initial root soluble sugars and TNC contents and concentrations in pre-transplant seedlings showed significant responses to nursery-applied treatments (Tab. 1). Initial root soluble sugar content and concentration in the F100- and F200+ treatments were at least 20\% higher than those in the F100+ treatment (Fig. 1), and the highest TNC content was detected in the F200+ treatment (Fig. 1A). The main effect of organic amendment on soluble sugar concentration was found to be significant (Tab. 1). 
Tab. 1 - $F$ values from ANOVA for the influence of inorganic fertilizer $(F)$, organic amendment $(O)$, and their interaction $(F \times O)$ applied at nursery stage in 2009 on root carbohydrate contents, concentrations, and biomass accumulation in Changbai larch (Larix olgensis Henry) seedlings before and after transplant on 22 April and 22 June 2010, respectively. $(*): P<0.05 ;(*): P<0.01 ;(* * *): P<0.001$.

\begin{tabular}{|c|c|c|c|c|c|c|c|c|c|}
\hline \multirow{2}{*}{$\begin{array}{l}\text { Before/After } \\
\text { Transplant }\end{array}$} & \multirow{2}{*}{$\begin{array}{l}\text { Root Diameter } \\
(\mathrm{mm})\end{array}$} & \multirow{2}{*}{$\begin{array}{l}\text { Source of } \\
\text { variation }\end{array}$} & \multicolumn{3}{|c|}{ Carbohydrate content } & \multicolumn{3}{|c|}{ Carbohydrate concentration } & \multirow{2}{*}{ Biomass } \\
\hline & & & Sugars & Starch & TNC & Sugars & Starch & TNC & \\
\hline \multirow{3}{*}{$\begin{array}{l}\text { Before } \\
\text { (22 April 2010) }\end{array}$} & Whole roots & $\mathrm{F}$ & 0.75 & 2.65 & 2.56 & 0.01 & 2.78 & 1.93 & 0.66 \\
\hline & & 0 & 1.00 & 0.41 & 0.01 & $13.97^{* *}$ & 0.29 & 4.44 & 5.24 \\
\hline & & $\mathrm{F} \times 0$ & $38.09^{* * *}$ & 0.19 & $5.63^{*}$ & $85.30^{* * *}$ & 0.76 & $11.19^{*}$ & 0.09 \\
\hline After & $0-1$ & $\mathrm{~F}$ & 2.84 & 0.50 & 2.71 & 1.18 & 0.18 & 1.18 & 2.74 \\
\hline \multirow[t]{10}{*}{ (22 June 2010) } & & 0 & 3.09 & 0.38 & 0.65 & 1.42 & 1.78 & 0.01 & 4.85 \\
\hline & & $\mathrm{F} \times 0$ & 1.84 & 2.55 & 0.01 & 1.11 & 3.95 & 0.44 & 1.35 \\
\hline & & 0 & $6.30^{*}$ & 0.37 & 4.39 & $6.45^{*}$ & 0.10 & 4.03 & 0.30 \\
\hline & & $\mathrm{F} \times 0$ & 3.28 & 0.19 & 2.28 & 3.90 & 0.17 & 2.65 & 0.18 \\
\hline & $>2$ & $\mathrm{~F}$ & $11.68^{* *}$ & $6.03^{*}$ & $9.95^{*}$ & 1.98 & 0.88 & 1.62 & $94.83^{* * *}$ \\
\hline & & 0 & 1.95 & 0.16 & 0.82 & 0.77 & 1.52 & 1.50 & $101.51^{* * *}$ \\
\hline & & $\mathrm{F} \times 0$ & $5.50^{*}$ & 0.05 & $7.86^{*}$ & 3.32 & 0.27 & 2.52 & $5.82^{*}$ \\
\hline & Whole roots & $\mathrm{F}$ & $7.85^{*}$ & 1.83 & $5.52^{*}$ & 0.52 & 0.09 & 0.35 & $32.62^{* * *}$ \\
\hline & & 0 & 0.82 & 0.07 & 0.05 & 2.33 & 2.16 & 3.71 & $34.39 * * *$ \\
\hline & & $\mathrm{F} \times 0$ & $5.83^{*}$ & 0.81 & 0.01 & 0.84 & 1.41 & 0.27 & 3.75 \\
\hline
\end{tabular}

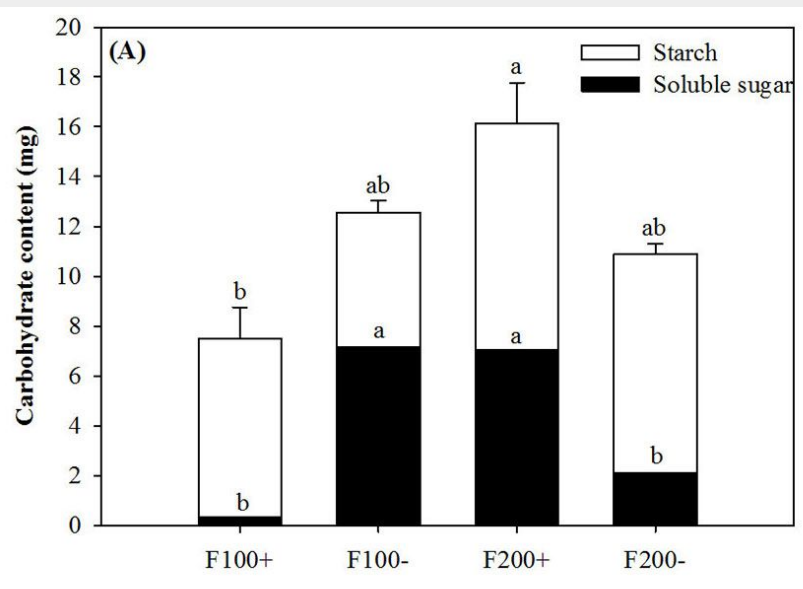

Fertilization treatment at nursery stage

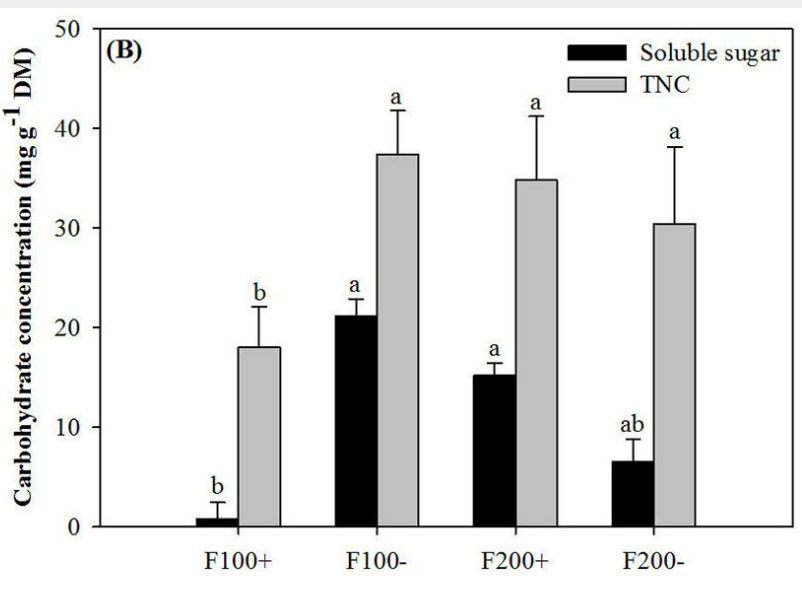

Fertilization treatment at nursery stage

Fig. 1 - Initial soluble sugar and starch contents (A) and soluble sugar and total non-structure carbohydrate (TNC) concentrations (B) in roots of Changbai larch seedlings before transplant on 22 April 2010 in response to combined treatments of inorganic fertilizer (F200 and F100) and organic amendment ("+" and "-") applied during nursery stage in 2009. Results for starch content were not statistically different. Different lowercase letters above columns indicate significant differences at $P<0.05$ level. Upper letters were labeled for TNC content and lower letters were labeled for soluble sugar content. Error bars indicate standard errors.

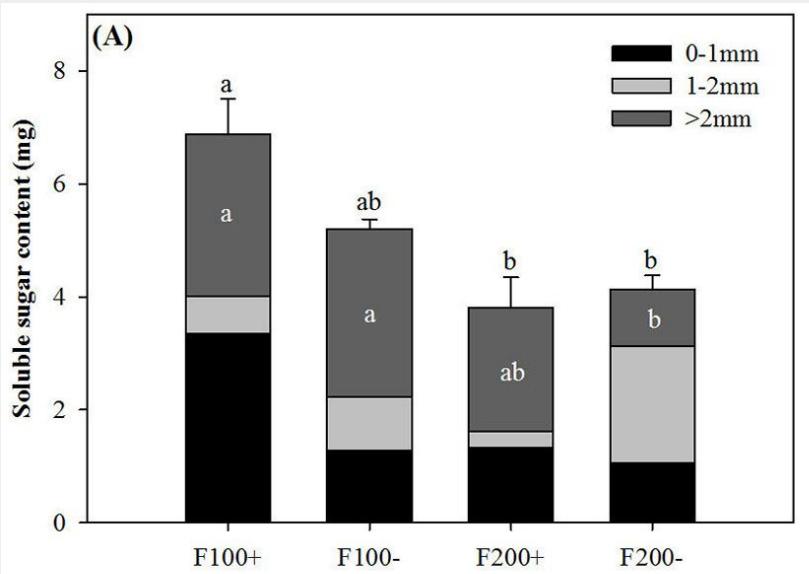

Fertilization treatment at nursery stage

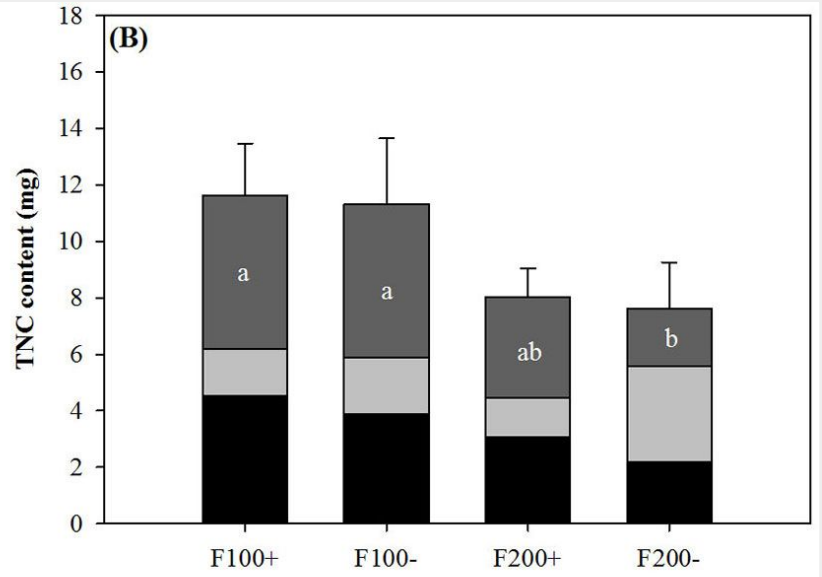

Fertilization treatment at nursery stage

Fig. 2 - Soluble sugar (A) and total non-structure carbohydrate (TNC) contents (B) of roots by diameter class (0-1 mm, 1-2 mm, and $>2 \mathrm{~mm}$ ) in Changbai larch seedlings two months after transplant on 22 June 2010 in response to combined treatments of inorganic fertilizer (F200 and F100) and organic amendment ("+" and "-") applied during nursery stage in 2009. Different lowercase letters above columns indicate significant differences at $P<0.05$ level. Error bars indicate standard errors. 

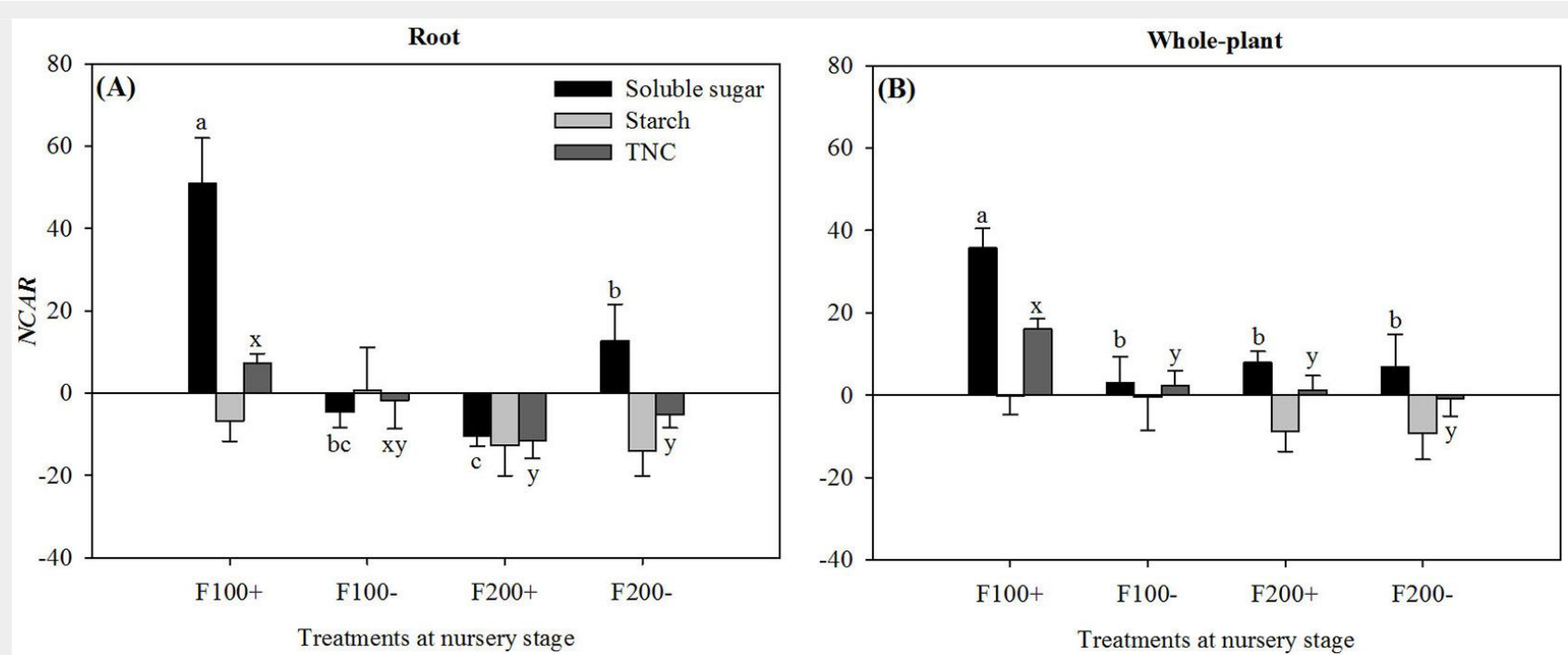

Fig. 3 - Net carbohydrate accumulation rates (NCAR) for soluble sugars, starch, and total non-structural carbohydrates in roots (A) and whole plants (B) for Changbai larch seedlings two months after transplant on 22 June 2010 in response to combined treatments of inorganic fertilizer (F200 and F100) and organic amendment ("+" and "-") applied during nursery stage in 2009. For a given chemical fraction, different lowercase letters above columns indicate significant differences at $P<0.05$. Significant means separations for soluble sugars are labeled as "a", "b", and/or "c", while those for TNC are labeled as x or y. Error bars indicate standard errors.

\section{Carbohydrate reserves in roots after transplant}

On 22 June 2010, both soluble sugar and TNC contents of coarse roots were greater in the F100+ and F100- than in the F200treatment (Fig. 2). For whole roots, soluble sugar content in the F100+ treatment was greater by $81 \%$ and $66 \%$ than that in the F200+ and F200- treatments, respectively (Fig. 2A). Inorganic fertilizer applications during the nursery stage significantly influenced root carbohydrate contents after transplant (Tab. 1). In coarse roots, starch content in the F10o treatment $(2.52 \pm 1.04$ $\mathrm{mg}$ ) was greater than that in the F200 treatment by $105 \%(1.23 \pm 0.26 \mathrm{mg})$. Organic amendment treatments during the nursery stage resulted in decreases of $67 \%$ and $69 \%$ for soluble sugar content $(+0: 0.49 \pm 0.26$ $\mathrm{mg}$; $-0: 1.50 \pm 0.99 \mathrm{mg}$ ) and concentration (+O: $10.10 \pm 5.42 \mathrm{mg} \mathrm{g}^{-1}$; $-0: 32.62 \pm 22.15 \mathrm{mg}$ $\left.\mathrm{g}^{-1}\right)$ in roots with diameter of $1-2 \mathrm{~mm}$,

respectively. Soluble sugar concentrations in post-transplant shoots on 22 June were $42.91 \pm 15.80 \mathrm{mg} \mathrm{g}^{-1}$, which was $120 \%$ higher relative to that in pre-transplant seedlings $(n=6, P=0.0075)$.

Tab. 2 - $F$ values from ANOVA for the influence of inorganic fertilizer $(F)$, organic amendment $(\mathrm{O})$, and their interaction $(\mathrm{F} \times \mathrm{O})$ applied at nursery stage in 2009 on root respiration rate and new root numbers in Changbai larch (Larix olgensis Henry) seedlings after transplant. $\left(^{*}\right): P<0.05$.

\begin{tabular}{lcccc}
\hline $\begin{array}{l}\text { Source of } \\
\text { variation }\end{array}$ & \multicolumn{3}{c}{ Root respiration } & $\begin{array}{c}\text { New root } \\
\text { number }\end{array}$ \\
\cline { 2 - 4 } $\mathrm{F}$ & $\mathbf{0 - 1 \mathrm { mm }}$ & $\mathbf{1 - 2 \mathrm { mm }}$ & $>2 \mathrm{~mm}$ & $6.96^{*}$ \\
$\mathrm{O}$ & $11.21^{*}$ & 3.60 & 0.35 & $11.07^{*}$ \\
$\mathrm{~F} \times 0$ & 2.84 & $5.79^{*}$ & 0.16 & $6.01^{*}$ \\
\hline
\end{tabular}
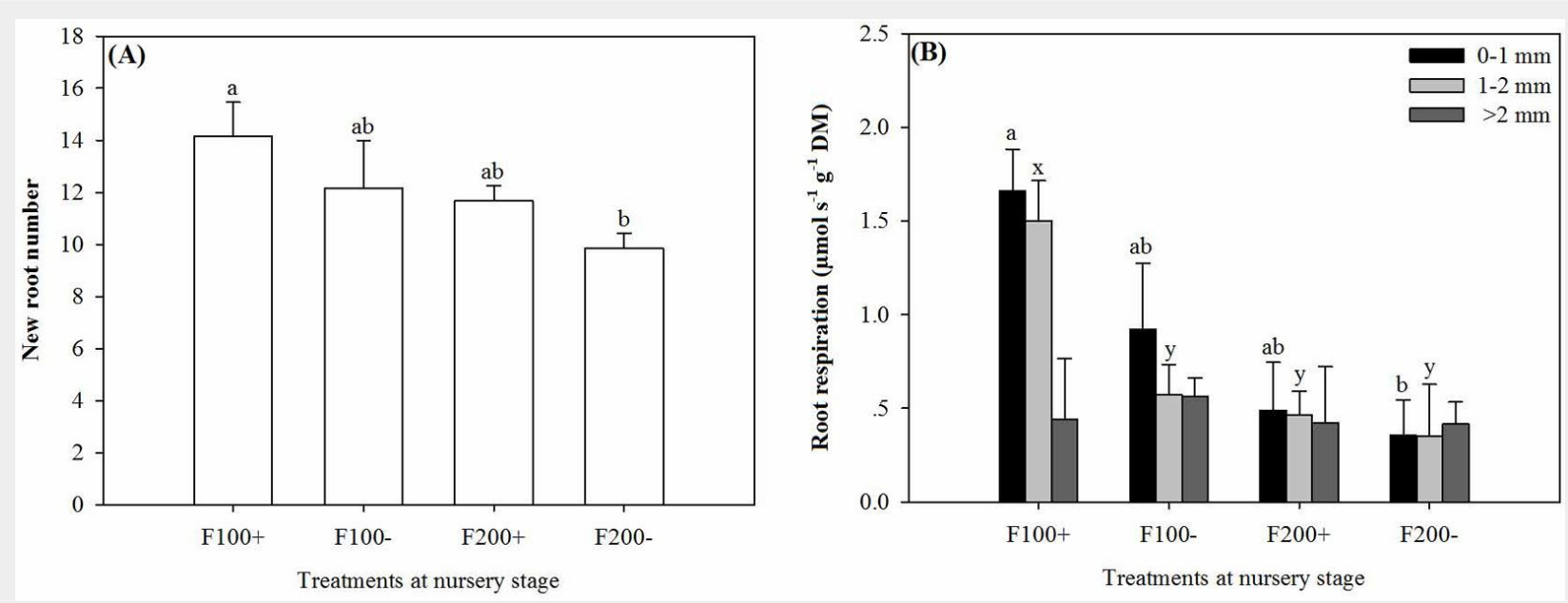

Fig. 4 - New root number (A) and respiration rate of roots by diameter class (0-1 mm, 1-2 mm, and >2 mm) (B) in Changbai larch seedlings two months after transplant on 22 June 2010 in response to combined treatments of inorganic fertilizer (F200 and F100) and organic amendment ("+" and "-") applied during nursery stage in 2009. Different lowercase letters above columns indicate significant differences at $P<0.05$. Significant means separations for roots 0-1 mm diameter are labeled with "a" and " $b$ ", while those for roots of 1-2 mm diameter are labeled with " $x$ " and " $y$ ". Error bars indicate standard errors. 


\section{Post-transplant carbohydrate} metabolism

During the first two months after transplant, there were significant interaction effects between nursery-applied inorganic fertilizer and organic amendment treatments on NCARs for soluble sugars $(P=$ 0.0227 and $P=0.0264)$ and TNC $(P<0.0001$ and $P=0.0020)$ at both root and wholeplant scales. NCARs for both soluble sugars and TNC were the highest in the $\mathrm{F} 100+$ treatment. Most values of NCAR for starch were negative and not statistically different among treatments (Fig. 3). Root NCAR for soluble sugars was higher in the F200treatment than in the F200+ treatment.

\section{Post-transplant biomass accumulation in roots}

On 22 June 2010, coarse root biomass was the greatest in the F100+ treatment (194.36 $\pm 11.98 \mathrm{mg}$ ), followed by the F100- and F200+ treatments $(118.98 \pm 12.83 \mathrm{mg}$ and $121.01 \pm 14.86 \mathrm{mg}$, respectively), and reached the least value in the F200- treatment $(74.76 \pm 2.17 \mathrm{mg}-P=0.0423)$. Seedlings receiving organic amendment during nursery stage had greater whole-root biomass by $38 \%$ (+O: $0.33 \pm 0.06 \mathrm{mg} ;-0: 0.24 \pm$ $0.04 \mathrm{mg}-P=0.0004)$, while seedlings in the F100- treatment had greater wholeroot biomass than those in the F100+ treatment $(0.33 \pm 0.07 \mathrm{mg}$ and $0.24 \pm 0.04 \mathrm{mg}$, respectively $-P=0.0003$ ).

\section{New root growth and root respiration}

The interaction between organic amendment and inorganic fertilizer treatments significantly affected new root numbers (Tab. 2). From 22 April to 22 June 2010, seedlings in the $\mathrm{F} 100+$ treatment developed the most new roots, which was $44 \%$ more than those observed in the F200treatment (Fig. 4A).

The interaction of organic amendment and inorganic fertilizer treatments could also influence root respiration rate (Tab. 2 ). Respiration rates in fine roots of $0-1 \mathrm{~mm}$ and $1-2 \mathrm{~mm}$ in diameter were higher in the $\mathrm{F} 100+$ treatment than in the F200- treatment $(P=0.0286$ and 0.0195 , respectively), but similar results was not detected for coarse roots (Fig. 4B).

\section{Discussion}

During nursery culture, Changbai larch seedlings were applied with approximately 18 or $36 \mathrm{mg} \mathrm{N}$ seedling $^{-1}$, respectively, but received a total dose of about $112 \mathrm{mg} \mathrm{N}$ seedling ${ }^{-1}$ in solution during the first two months after transplant. Thus, the overall fertilizer dose in the second year was higher than that applied in the first year, and the high level of $\mathrm{N}$ supplied in solution after transplant likely had some effects on transplanted seedling roots. The dose of $112 \mathrm{mg} \mathrm{N}$ seedling ${ }^{-1}$ in our study was much lower than those used for transplanted stocks in studies from Spain (Oliet et al. 2009) and USA (Jacobs et al. 2005). All seedlings received a uniform dose during the post-transplant growth phase; consequently, post-transplant solution-supplied $\mathrm{N}$ was unlikely to result in different root responses observed in this study. In an applied context, the nutrient-enriched solution provided to seedlings in this study could simulate transplant conditions in necessary situations where seedlings are supplied with controlled-released fertilizer at out-planting to improve their potentially future performance (Oliet et al. 2009, Sloan \& Jacobs 2013).

\section{Biomass accumulation}

The great root biomass observed in the $\mathrm{F} 100+$ treatment resulted from TNC accumulation in coarse roots where root biomass and TNC accumulation had a significant positive correlation $(n=12, R=0.5764$, $P=0.0498$ ). Coarse roots provide structural support to transplanted seedling growth through secondary thickening (COsta et al. 2014). However, according to Wilson et al. (2007) and Wei et al. (2013), greater root biomass with larger tap and woody roots may lead to two main results of $\mathrm{N}$ uptake by fine roots: to limit the proliferation of fine roots but to promote the rate of $\mathrm{N}$ influx into fine root cells. In the present study, greater root biomass was observed in the lower rate of inorganic fertilizer treatment and in the organic amendment treatment, both of which coincided with TNC accumulation in coarse roots. Thus, according to these biomass accumulation results, we accept our first hypothesis.

\section{Root respiration and new root growth}

The trend in declining respiration rates with increasing root diameter which appeared in our study has already been identified for mature trees (Chen et al. 2010, Jia et al. 2013). Fine root respiration rate changes among treatments coincided with general patterns observed for soluble sugars, TNC, and biomass accumulation in coarse roots, potentially suggesting the function of root carbohydrate storage to fuel root respiration (Anderson et al. 2010). Intensive soluble sugar depletion by respiration during new root growth has also been shown in cuttings of some Pelargonium species (Druege \& Kadner 2008). Additionally, both carbohydrate decline (Druege et al. 2004) and root respiration (Reich et al. 1998) are related to inherent $N$ status, which was controlled by nurseryapplied treatments. Hence, it is reasonable to accept our second hypothesis.

Higher respiration rates of roots of posttransplant seedlings in the lower rate of the inorganic fertilizer treatment may resulted from a greater seedling $\mathrm{N}$ reserve (Druege et al. 2000), which usually contributes to more new root egress (Cuesta et al. 2010a, 2010b) because many critical functions during new root growth depend upon root respiration for an energy supply (Reich et al. 1998, Apostol et al. 2007). In a previous study, Wei et al. (2012a) reported that a lower rate of the inorganic fertilizer treatment promoted seedling quality by enhancing $\mathrm{N}$ reserves. This conclusion was continuously strengthened in our study, likely due to more new root egress in the same treatment (Apostol et al. 2007, Sloan \& Jacobs 2008, Carles et al. 2011). On the other hand, the nursery-applied organic amendment treatment also resulted in more new roots after transplant, which was attributed to better initial root quality as characterized by tap root length and lateral root number before transplant (Wei et al. 2012a, Wilson et al. 2007). Therefore, the final result of more root number in the F100+ treatment was related to a continuous influence from nursery treatments through the changes of root respiration.

\section{Carbohydrate accumulation before transplant}

Before transplant, starch storage in initial roots was not different for either content or concentration among nursery treatments. Temperature during storage can lead to starch depletion throughout the period from seedling lifting at fall to transplant at spring (Pagter \& Arora 2013). During this time, starch is depleted mainly through respiration. Also carbohydratemetabolism-related enzymatic activity can at least partly result in starch depletion, such as starch granule bound endoamylase and starch phosphorylase (Elle \& Sauter 2000). Therefore, the null effect of nursery treatments on initial starch status might result from the temperature impact during storage. However, the proportion of starch to TNC reserves was as high as $68 \%$ in initial roots of Changbai larch seedlings in this study, which was higher than that in roots of Sabina prezewalskii Kom. (SP), S. Chinensis (Lin.) Ant. (SC) ( 38\% - Chen et al. 2012), and some poplar species ( $\sim 35 \%$ - Regier et al. 2010). In our study, although Changbai larch seedlings suffered some level of transplant shock during processes of seedling lifting, moving out of storage, and removal of soils at root-surface (Druege et al. 2000, Wang \& Zwiazek 2001), the high proportion of starch to TNC suggests that the substantial starch reserves within seedlings may not have been depleted intensively at the beginning of the growth chamber experiment. Transplant shock was unlikely to seriously interfere with initial carbohydrate status. Nevertheless, decline of soluble sugars in the $\mathrm{F} 100+$ treatment in initial seedling roots led to differentiation of carbohydrate statuses among treatments. According to former results, greater $\mathrm{N}$ reserves were created in annual organs of seedlings in the F100+ treatment at the end of nursery cultivation due to greater biomass accumulation and higher $\mathrm{N}$ concentration in stems (Wei et al. 2012a). These additional $\mathrm{N}$ reserves in seedlings in the $\mathrm{F} 100+$ treatment may have resulted in increased carbohydrate consumption and the devotion of more assimilated carbon to growing structures (Margolis \& Waring 
1986, Druege et al. 2000, 2004). For Changbai larch seedlings, it has also been reported that nursery fertilization would result in starch depletion (Wei et al. 2014).

Post-transplant carbohydrate metabolism and accumulation

During the period from 22 April to 22 June 2010, starch was intensively depleted, resulting in negative values of NCAR for starch at both root and whole-plant scales. Starch reduction in early stages of posttransplant seedling growth was caused by shoot growth (Willaume \& Pagès 2011) and new root egress (Sloan \& Jacobs 2008, Vargas et al. 2009, Willaume $\&$ Pagès 2011). We employed the low light intensity of 150 $\mu \mathrm{mol} \mathrm{m} \mathrm{m}^{-2}$ with the aim of mimicking the natural conditions of Changbai larch regeneration, but this light intensity was also found to result in poor performance of regenerated Changbai larch seedlings (Zhu et al. 2008). Some studies have reported that light compensation point (LCP) for

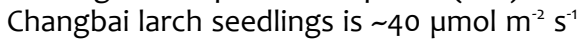
(Zhao et al. 2007, Mao et al. 2010), while the $L C P$ for this species ranged from 100 to $170 \mu \mathrm{mol} \mathrm{m}^{-2} \mathrm{~s}^{-1}$ (Wang et al. 2002). Hence, we surmise that the light intensity at 150 $\mu \mathrm{mol} \mathrm{m} \mathrm{m}^{-2} \mathrm{~s}^{-1}$ in the present study may be insufficient to support the growth of Changbai larch seedlings and may have impaired their net $\mathrm{C}$ assimilation (Schluter et al. 2003, Druege et al. 2004). According to our results about starch metabolism, lower starch concentration in the F200+ treatment could be attributed to a greater starch depletion in shoots due to inefficient starch production under the low light intensity. The nursery-applied organic amendment treatment resulted in a significant effect on fine roots in initial seedlings, but had no effect on $\mathrm{N}$ reserves (Wei et al. 2012a), which led to the lack of response observed for current-season starch metabolism.

In the F100- and F200+ treatments, values of NCAR for soluble sugars were negative in roots but positive at the whole-plant scale. Aside from the impact of insufficient photosynthetic production under the low light intensity, these results also suggest that most soluble sugars were retained in shoots, leading to intensive soluble sugar depletion in roots (Margolis \& Waring 1986). Compared to these two treatments, final root soluble sugar contents were greater in the $\mathrm{F} 100+$ treatment, suggesting that seedlings in the F100+ treatment were more efficient to assimilate soluble sugars for new root formation (Druege \& Kadner 2008) compared to those in the F100treatment. Greater soluble sugar content in whole roots of seedlings in the lower rate of inorganic fertilizer treatment resulted from the greater soluble sugar accumulation in coarse roots, suggesting a lowcost of consumption of soluble sugars for new root growth in this treatment.

\section{Conclusions}

This study indicated that, relative to the inorganic fertilizer treatment at nursery stage, a lower rate of inorganic fertilizer treatment with organic additive could benefit roots of post-transplanted Changbai larch seedlings in carbohydrate assimilation, biomass accumulation, and fine root respiration. The effect of the single treatment of inorganic fertilizer supplied at 200 $\mathrm{kg} \mathrm{N} \mathrm{ha-1}$ can be overcome by the treatment of half-dose-rate of $100 \mathrm{~kg} \mathrm{~N} \mathrm{ha}^{-1}$ with chicken manure added at the rate of $100 \mathrm{~kg}$ $\mathrm{N}$ ha ${ }^{-1}$. Obviously, the implementation of organic amendment contributed to the relief of contamination through the replacement of some inorganic fertilizers. Our results also highlight the potential of incorporating organic amendments into the cultural protocol of larch seedling culture so as to improve their quality and transplant performance, but the application should be considered to be employed in the context with interactive inorganic fertilizers at a reasonable rate.

\section{Acknowledgements}

This work was supported by the "Dalian Science and Technology Project (2014B11 NC078)", "Key Deployment Project of Chinese Academy of Sciences (KFZD-SW-30203)", "Natural Science Foundation of China (31170168)", "National Spark Program project (2013GA651006)", "National Torch Plan Project (2012GH531899)", "Program for Liaoning Excellent Talents in University (LR2013055)", and "Liaoning province science and technology plan (2011209001)".

\section{References}

Aghai MM, Pinto JR, Davis AS (2014). Container volume and growing density influence western larch (Larix occidentilis Nutt.) seedling development during nursery culture and establishment. New Forests 45 (2): 199-213. - doi: 10.1007 /s11056-013-9402-8

Anderson LJ, Derner JD, Polley HW, Gordon WS, Eissenstat DM, Jackson RB (2010). Root response along a subambient to elevated $\mathrm{CO}_{2}$ gradient in a C-3-C-4 grassland. Global Change Biology 16 (1): 454-468. - doi: 10.1111/j.1365-2486. 2009.01975.x

Apostol KG, Jacobs DF, Wilson BC, Salifu KF, Dumroese RK (2007). Growth, gas exchange, and root respiration of Quercus rubra seedlings exposed to low root zone temperature in solution culture. Forest Ecology and Management 253(1-3): 89-96. - doi: 10.1016/j.foreco.2007.04. 054

Carles S, Lamhamedi MS, Stowe DC, Bernier PY, Veileux L, Margolis HA (2011). Relationship between frost hardiness, root growth potential, and photosynthesis of nursery-grown white spruce seedlings. Annals of Forest Science 68 (8): 1303-1313. - doi: 10.1007/s13595-011-0138-3

Chen DM, Zhou LX, Rao XQ, Lin YB, Fu SL (2010). Effects of root diameter and root nitrogen concentration on in situ root respiration among different seasons and tree species. Ecological Research 25 (5): 983-993. - doi: 10.1007/s11284-0100722-2
Chen T, Pei HJ, Zhang YF, Qian QL (2012). Seasonal changes in non-structural carbohydrates and sucrose metabolism enzymes in two Sabina species. Acta Physiologiae Plantarum 34 (1): 173-180. - doi: 10.1007/s11738-011-0815-8

Costa TL, Sampaio EVSB, Sales MF, Accioly LJO, Althoff TD, Pareyn FGC, Albuquerque ERGM, Menezes RSC (2014). Root and shoot biomasses in the tropical dry forest of semi-arid Northeast Brazil. Plant and Soil 378 (1-2): 113123. - doi: 10.1007/s11104-013-2009-1

Cuesta B, Vega J, Villar-Salvador P, Rey-Benayas JM (2010a). Root growth dynamics of Aleppo pine (Pinus halepensis Mill.) seedlings in relation to shoot elongation, plant size and tissue nitrogen concentration. Trees - Structure and Function 24 (5): 899-908. - doi: 10.1007/s00468-0100459-0

Cuesta B, Villar-Salvador P, Puértolas J, Jacobs DF, Rey Benaya JM (2010b). Why do large, nitrogen rich seedlings better resist stressful transplanting conditions? A physiological analysis in two functionally contrasting Mediterranean forest species. Forest Ecology and Management 260 (1): 71-78. - doi: 10.1016/j.foreco.20 10.04.002

Davis AS, Jacobs DF, Wightman KE, Birge ZKD (2006). Organic matter added to bareroot nursery beds influences soil properties and morphology of Fraxinus pennsylvanica and Quercus rubra seedlings. New Forests 31: 293-303. - doi: 10.1007/s11056-005-7484-7

Druege U, Zerche S, Kadner R, Ernst M (2000). Relation between nitrogen status, carbohydrate distribution and subsequent rooting of Chrysanthemum cuttings as affected by preharvest nitrogen supply and cold-storage. Annals of Botany 85 (5): 687-701. - doi: 10.1006/ anbo.2000.1132

Druege U, Zerche S, Kadner R (2004). Nitrogenand storage-affected carbohydrate partitioning in high-light-adapted Pelargonium cuttings in relation to survival and adventitious root formation under low light. Annals of Botany 94 (6): 831-842. - doi: 10.1093/aob/mch210

Druege U, Kadner R (2008). Response of poststorage carbohydrate levels in Pelargonium cuttings to reduced air temperature during rooting and the relationship with leaf senescence and adventitious root formation. Postharvest Biology and Technology 47 (1): 126-135. - doi: 10.1016/j.postharvbio.2007.06.008

Duan J, Xu CY, Jacobs DF, Ma LY, Wei HX, Jiang LN, Ren J (2013). Exponential nutrient loading shortens the cultural period of Larix olgensis seedlings. Scandinavian Journal of Forest Research 28 (5): 409-418. - doi: 10.1080/02827581. 2013.778328

Eilmann B, Rigling A (2012). Tree-growth analyses to estimate tree species's drought tolerance. Tree Physiology 32 (2): 178-187. - doi: 10.1093/treephys/tpso04

Elle D, Sauter JJ (2000). Seasonal changes of activity of a starch granule bound endoamylase and of a starch phosphorylase in poplar wood (Populus $\times$ canadensis Moench 'Robusta') and their possible regulation by temperature and phytohormones. Journal of Plant Physiology 156 (5-6): 731-740. - doi: 10.1016/S0176-1617(00) 80239-4

Irshad M, Malik AH, Shaukat S, Mushtaq S, As- 
hraf M (2013). Characterization of heavy metals in livestock manures. Polish Journal of Environmental Study 22 (4): 1257-1262. [online] URL: http://www.pjoes.com/pdf/22.4/Pol.J.Environ.S tud.Vol.22.No.4.1257-1262.pdf

Jacobs DF, Salifu KF, Seifert JR (2005). Growth and nutritional response of hardwood seedlings to controlled-release fertilization at outplanting. Forest Ecology and Management 214: 28-39. - doi: 10.1016/j.foreco.2005.03.053 Jia SX, McLaughlin NB, Gu JC, Li XP, Wang ZQ (2013). Relationships between root respiration rate and root morphology, chemistry and anatomy in Larix gmelinii and Fraxinus mandshurica. Tree Physiology 33 (6): 579-589. - doi: 10.1093/treephys/tpto40

Klooster WS, Cregg BM, Fernandez RT, Nzokou $P$ (2012). Growth and physiology of deciduous shade trees in response to controlled-release fertilizer. Scientia Horticulturae 135: 71-79. - doi: 10.1016/j.scienta.2011.12.009

Mao ZJ, Zhao XZ, Liu LX, Jiang HF (2010). Photosynthetic physiological characteristics in response to elevated $\mathrm{CO}_{2}$ concentration of three larch (Larix) species seedlings. Acta Ecologica Sinica 30 (2): 317-323. [in Chinese]

Margolis HA, Waring RH (1986). Carbon and nitrogen allocation patterns of Douglas-fir seedlings fertilized with nitrogen in autumn. I. Overwinter metabolism. Canadian Journal of Forest Research 16 (5): 897-902. - doi: 10.1139/x86-160 Oliet JA, Tejada M, Salifu KF, Collazos A, Jacobs DF (2009). Performance and nutrient dynamics of holm oak (Quercus ilex L.) seedlings in relation to nursery nutrient loading and post-transplant fertility. European Journal of Forest Research 128: 253-263. - doi: 10.1007/s10342-0090261-y

Pagter M, Arora R (2013). Winter survival and deacclimation of perennials under warming climate: physiological perspectives. Physiologia Plantarum 147: 75-87. - doi: 10.1111/j.1399-3054. 2012.01650.x

Park BB, Cho MS, Lee SW, Yanai RD, Lee DK (2012). Minimizing nutrient leaching and improving nutrient use efficiency of Liriodendron tulipifera and Larix leptolepis in a container nursery system. New Forests 43 (1): 57-68. - doi: 10.1007/s11056-011-9266-8

Regier N, Streb S, Zeeman SC, Frey B (2010). Seasonal changes in starch and sugar content of poplar (Poplus deltoides $\times$ nigra cv. Dorskamp) and the impact of stem girdling on carbohydrate allocation to roots. Tree Physiology 30 (8): 979-987. - doi: 10.1093/treephys/tpq047 Reich PB, Walters MB, Tjoelker MG, Vanderklein $D$, Buschena C (1998). Photosynthesis and respiration rates depend on leaf and root morphology and nitrogen concentration in nine boreal tree species differing in relative growth rate. Functional Ecology 12 (3): 395-405. - doi: 10.1046/j.1365-2435.1998.00209.x

Salifu KF, Jacobs DF (2006). Characterizing fertility targets and multi-element interactions in nursery culture of Quercus rubra seedlings.
Annals of Forest Science 63: 231-237. - doi: 10.1051/forest:2006001

Schluter U, Muschak M, Berger D, Altmann T (2003). Photosynthetic performance of an Arabidopsis mutant with elevated stomatal density (sdd1-1) under different light regimes. Journal of Experimental Botany 54 (383): 867-847. - doi: 10.1093/jxb/erg087

Sloan JL, Jacobs DF (2008). Carbon translocation patterns associated with new root proliferation during episodic growth of transplanted Quercus rubra seedlings. Tree Physiology 28 (7): 11211126. - doi: 10.1093/treephys/28.7.1121

Sloan JL, Jacobs DF (2013). Fertilization at planting influences seedling growth and vegetative competition on a post-mining boreal reclamation site. New Forests 44 (5): 687-701. - doi: 10.1007/s11056-013-9378-4

Vargas R, Trumbore SE, Allen MF (2009). Evidence of old carbon used to grow new fine roots in a tropical forest. New Phytologist 182 (3): 710-718. - doi: 10.1111/j.1469-8137.2009.027 89.x

Wang YF, Zwiazek JJ (2001). Physiological characteristics and carbohydrate contents of spring-lifted Picea glauca bareroot seedlings following low-temperature storage. Scandinavian Journal of Forest Research 16 (5): 415-421. - doi: $10.1080 / 02827580152632801$

Wang M, Hao ZQ, Ji LZ, Zhou GS (2002). Effect of elevated atmospheric $\mathrm{CO}_{2}$ concentrations on photosynthesis light response characteristics of three coniferous tree species seedlings. Chinese Journal of Applied Ecology 13 (6): 646650. [in Chinese] [online] URL: http://europe pmc.org/abstract/med/12216385

Watanabe M, Ryu K, Kita K, Takagi K, Koike T (2012). Effect of nitrogen load on growth and photosynthesis of seedlings of the hybrid larch F-1 (Larix gmelinii var. japonica $\times$ L. kaempferi) grown on serpentine soil. Environmental and Experimental Botany 83: 73-81. - doi: 10.1016/j. envexpbot.2012.04.011

Wei HX, Xu CY, Ma LY, Jiang LN, Chai Y, Jia ZK (2011). Leaching of mineral nitrogen and available phosphorus during culture of bareroot Larix olgensis seedlings under native fertilizer management in Northeastern China. In: Proceedings of the "Computer Distributed Control and Intelligent Environmental Monitoring (CDCIEM), 2011 International Conference". Changsha (Hunan, China), 19-20 Feb 2011. WileyIEEE Press, IEEE Computer Society, Los Alamitos, CA, USA, pp. 1247-1252. [online] URL: http://ieeexplore.ieee.org/document/5748040/ Wei HX, Xu CY, Hawkins BJ, Ma LY, Jiang LN (2012a). Organic amendment and inorganic fertilization affect soil properties and quality of Larix olgensis bareroot seedling. New Forests 43 (2): 155-168. - doi: 10.1007/s11056-011-9270-z

Wei HX, Xu CY, Ma LY, Duan J, Jiang LN, Ren J (2012b). Nitrogen retranslocation, allocation, and utilization in bare root Larix olgensis seedlings. Journal of Forestry Research 23 (1): 87-94. - doi: 10.1007/s11676-012-0237-5
Wei HX, Xu CY, Ma LY, Ren J (2013). Newly transplanted Larix olgensis Henry seedling with greater root biomass has higher early nitrogen flux rate. Soil Science and Plant Nutrition 59 (5): 740-749. - doi: 10.1080/00380768.2013.816 977

Wei HX, Xu CY, Ma LY, Duan J, Jiang LN, Ren J (2014). Effect of late-season fertilization on nutrient reserves and carbohydrate accumulation in bareroot Larix olgensis seedlings. Journal of Plant Nutrition 37 (2): 279-293. - doi: 10.1080/01904167.2013.859697

Willaume M, Pagès L (2011). Correlated responses of root growth and sugar concentrations to various defoliation treatments and rhythmic shoot growth in oak tree seedlings (Quercus pubescens). Annals of Botany 107 (4): 653-662. - doi: 10.1093/aob/mcq270

Wilson ER, Vitols KC, Park A (2007). Root characteristics and growth potential of container and bare-root seedlings of red oak (Quercus rubra L.) in Ontario, Canada. New Forests 34: 163-176. - doi: 10.1007/s11056-007-9046-7

Xu QH, Liu Y, Ma LY, Li YA (2010). Relationship between transpiration rate of Larix olgensis and meteorologic element. Journal of Northwest Forestry University 25 (3): 12-14. [in Chinese] [online] URL: http://en.cnki.com.cn/Article_en/ CJFDTOTAL-XBLX201003002.htm

You WZ, Wei WJ, Zhang HD, Yan TW, Xing ZK (2013). Temporal patterns of soil $\mathrm{CO}_{2}$ efflux in a temperate Korean larch (Larix olgensis Henry) plantation, Northeast China. Trees - Structure and Function 27 (5): 1417-1428. - doi: 10.1007/ s00468-013-0889-6

Zhang FS, Li XY (1984). Characteristics of temperature and humidity in growing season for main forest types in the northern slope of Changbai Mountain. In: "Forest Ecosystem Research IV”. China Forestry Press, Beijing, China, pp. 243-251. [in Chinese]

Zhang XS (2007). The vegetation map of the People's Republic of China (1:1.000.000). The Geological Publishing House (GPH) Press, Beijing, China. [online] URL: http://english.ib.cas. cn/Research/Achievements/200904/t20090403 1447.html

Z̄hang PC, Shao GF, Zhao G, Le Master DC, Parker GR, Dunning JB, Li QL (2000). China's forest policy for the $21^{\text {st }}$ century. Science 288 (5474): 2135-2136. - doi: 10.1126/science.288.5474.2135

Zhao XJ, Jiang HF, Mao ZJ (2007). The studies of the photosynthetic characteristics of Larix olgensis Henry, Larix kaempferi Carr. and Larix gmelinii Rupr. seedlings. Bulletin of Botanical Research 27 (3): 361-366. [in Chinese] [online] URL: http://europepmc.org/abstract/cba/6383 66

Zhu JJ, Liu ZG, Wang HX, Yan QL, Fang HY, Hu LL, Yu LZ (2008). Effects of site preparation on emergence and early establishment of Larix olgensis in montane regions of northeastern China. New Forests 36: 247-260. - doi: 10.1007/ s11056-008-9097-4 